\title{
EFFECT OF INDIVIDUAL OR COMBINED APPLICATION OF HERBICIDE IMAZETHAPYR ON NUTRIENT UPTAKE BY BLACKGRAM (Vigna mungo L.)
}

\author{
Gurdeep Singh Malhi ${ }^{1}$, M.C. Rana ${ }^{2}$, S.S. Rana ${ }^{2}$, Prashant Kaushik ${ }^{3 *^{*}}$ \\ ${ }^{1}$ Department of Agronomy, Punjab Agricultural University, Ludhiana, Punjab, 141004, India \\ ${ }^{2}$ Department of Agronomy, Forages and Grassland Management, CSK Himachal Pradesh Krishi Vishvavidyalaya, Palampur, Himachal Pradesh 176062, India \\ ${ }^{3}$ Instituto de Conservación y Mejora de la Agrodiversidad Valenciana, UniversitatPolitècnica de València, 46022 Valencia, Spain
}

Received - April 05, 2020; Revision - June 04, 2020; Accepted - August 02, 2020

Available Online - August 25, 2020

DOI: http://dx.doi.org/10.18006/2020.8(4).441.446

\section{KEYWORDS \\ Black gram \\ Imazethapyr \\ Nutrient uptake \\ Pendimethalin, \\ Weed}

\section{* Corresponding author}

E-mail: prakau@doctor.upv.es (Prashant Kaushik)

"Nagano University, 1088 Komaki, Ueda, 386-0031 Nagano, Japan.

Peer review under responsibility of Journal of Experimental Biology and Agricultural Sciences.

Production and Hosting by Horizon Publisher India [HPI] (http://www.horizonpublisherindia.in/).

All rights reserved.

\begin{abstract}
A field experiment was conducted to study the influence of individual or combined application of imazethapyr herbicide on nutrients depletion by weeds in black gram at Berthin, Bilaspur district of Himachal Pradesh, India. Twelve weed control treatments viz., imazethapyr at $70 \& 80 \mathrm{~g} / \mathrm{ha}$ as preemergence and 3-4 leaf stage, ready mix combination of imazethapyr + imazamox $70 \& 80 \mathrm{~g} / \mathrm{ha}$ as preemergence and at 3-4 leaf stage, pendimethalin at $1000 \mathrm{~g} / \mathrm{ha}$ as pre-emergence, ready mix combination of imazethapyr + pendimethalin $1000 \mathrm{~g} / \mathrm{ha}$ as pre-emergence, hand weeding twice (25 \&45 DAS) and unweeded check were tested in a randomized block design (RBD) with three replications to determine the most efficient treatment. The results of the study revealed that the NPK uptake by blackgram was enhanced on the application of all weed management treatments. Further, a reduction in the depletion of the nutrients by weeds was also reported in all treatments. Among the various treatments, pre-emergence application of ready mix compound imazethapyr + imazamox $80 \mathrm{~g}$ /ha was found the best treatment, this was followed the combined application of imazethapyr + imazamox $70 \mathrm{~g} / \mathrm{ha}$, these two do not significantly different to each other. Overall, a higher uptake of nutrients by weeds in weedy checks tended to decrease available NPK in soil necessitating the control of weeds in the production system.
\end{abstract}

All the articles published by Journal of Experimental Biology and Agricultural Sciences are licensed under a Creative Commons Attribution-NonCommercial 4.0 International License Based on a work at www.jebas.org.

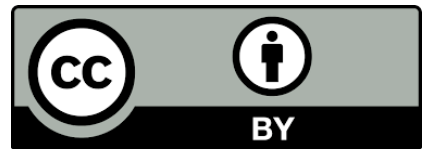




\section{Introduction}

Pulses belong to the family Fabaceae and constitute an important source of proteins $(22 \%)$ for the 40 percent vegetarian population of India (Avinash \& Patil, 2018). Along with biological nitrogen fixation, it helps in the reduction of greenhouse gases emission by 5-7 times as compared to other crops (Stagnari et al., 2017). India is the largest pulses producer, importer, consumer, and processor in the world. The total world area under pulses cultivation is about 85.40 Mha with an annual production of $87.40 \mathrm{mt}$ and a productivity of $1023 \mathrm{~kg} / \mathrm{ha}$. India cultivates around 24 percent of the world's area under pulses and produces around 26 percent of the world's production. Blackgram is one of the important pulse crops grown in India over an area of 5.44 Mha (Kharif + rabi) with a production of $3.56 \mathrm{mt}$ and productivity of $655 \mathrm{~kg} / \mathrm{ha}$ (Anonymous, 2018). In Himachal Pradesh, it is cultivated over an area of 9000 ha with a production of 7000 tonnes and productivity of $733 \mathrm{~kg} / \mathrm{ha}$ (Tiwari \& Shivhare, 2016). The yield in the state is higher than the national average yield but far below the potential yield (1600 kg ha $\left.{ }^{-1}\right)$ of the crop witnessed (Rana et al., 2019a). Among the various constraints to realize its potential yield, weeds are the major hindrance in exploiting the full utilization of production factors for higher yield. The common weeds associated with blackgram are Echinochloa colonum, Sorghum halepense, Echinochloa crusgalli, Cyperus rotundus, Commelina benghalensis, Cyperus iria, Cynodon dactylon, Cleome viscose, Trianthema monogyna, Amaranthus spp, Eleusine indica and Physalis minima (Shweta et al., 2017; Rana et al., 2019b; Pankaj et al., 2020). Weeds compete for water, light, and deplete nutrients from the soil resulting in a drastic decline of 66.67 percent yield in blackgram if grown uncontrolled (Mansoori et al., 2015). In general, weeds have a higher nutrient requirement and will absorb nutrients more than the crop. Choudhry et al. (2012) reported that blackgram is less competitive against numerous weeds during the first stages of crop especially 3 to 6 weeks after sowing

The nutrient (NPK) uptake by the blackgram is significantly enhanced with the adoption of weed management technology along with a reduction in nutrients removal by weeds. The weed management by herbicides in a tropical country like India is very efficient since a wide spectrum of weeds is observed here. Still, the continuous use of herbicides can lead to the development of resistant weeds or cause residue accumulation in the succeeding crops. The commonly used pre-emergence herbicides are alachlor, pendimethalin, fluchloralin, nitrofen, etc. Whereas, imazethapyr, quizalofop-ethyl, and clodinafop-propargyl are among the commonly used post-emergence herbicides (Sanbagavalli et al., 2016). Pre-emergence herbicides have less persistence, so they aren't able to control the later flushes of weed growth. Imazethapyr is a board spectrum, a highly persistent herbicide that can be applied as pre-plant incorporation, pre-emergence, and postemergence has high soil and foliar activity and low toxicity to mammals (Tan et al., 2005; Sasikala et al., 2019). It can control all the annual grasses, perennial grasses, and broad-leaved weeds (Sondhia \& Varshney, 2010). However, a single herbicide is not able to control all types of weeds. Hence, the application of a mixture of herbicides widens the weed control spectrum, saves cost, time, and reduces the environmental impact of herbicides. A new class of herbicides belonging to the imidazolinone group, i.e., imazamox when used in combination with imazethapyr as a readymix herbicide have been found very efficient in controlling weeds in Blackgram (Upasani et al., 2017). In this direction, a treatment whose effect lasts until the critical period of crop weed competition will substantially help in reducing crop weed competition for nutrients in blackgram. The present investigation, therefore, was an attempt to estimate the removal of nutrients due to weeds and blackgram crops as influenced by post-emergence herbicide application under low hill conditions of Himachal Pradesh.

\section{Materials and Methods}

The current exploration was undertaken in an ongoing experiment at the research farm of Regional Research Substation, Berthin $\left(31^{\circ} 41^{\prime} \mathrm{N}\right.$ latitude, $76^{\circ} 62^{\prime} \mathrm{E}$ longitude as well as 661 meters altitude of Western Himalayas), Bilaspur during Kharif season 2015. The experimental site falls in the sub mountainous low hill zone of Himachal Pradesh. Agro-climatically, Berthin falls under the subtropical warm sub-humid zone of Himachal Pradesh. Weekly maximum, as well as minimum temperature, ranged from 31.4 to $34.9^{\circ} \mathrm{C}$ and 15.4 to $23.9^{\circ} \mathrm{C}$, respectively, during the growing season. The entire rainfall during the cropping season was reported $139.6 \mathrm{~mm}$, the weather remained warm with inconsistent rain during the period of crop growth and development. The soil of the test site was sandy loam, slightly alkaline ( $\mathrm{pH}$ 7.6), and has medium availability of NPK nutrients, i.e. $305 \mathrm{~kg} / \mathrm{ha} \mathrm{N}, 24.3 \mathrm{~kg} / \mathrm{ha}$ $\mathrm{P}_{2} \mathrm{O}_{5}$ and $249 \mathrm{Kg} / \mathrm{ha} \mathrm{K}_{2} \mathrm{O}$. Twelve weed control treatments viz., imazethapyr @ 70g/ha (pre-emergence), imazethapyr @ 80g/ha (pre-emergence), imazethapyr @ 70 g/ha (3-4 leaf stage), imazethapyr @ 80 g/ha (3-4 leaf stage), ready mix combinations of imazethapyr+imazamox@70 g/ha (pre-emergence), ready mix combinations of imazethapyr + imazamox @ 80g/ha (preemergence), ready mix combinations of imazethapyr + imazamox @ $70 \mathrm{~g} / \mathrm{ha}$ (3-4 leaf stage), ready mix combinations of imazethapyr + imazamox@80 g/ha (3-4 leaf stage), pendimethalin@1000 g/ha (pre-emergence), combination of imazethapyr + pendimethalin 1000 $\mathrm{g} / \mathrm{ha}$ as pre-emergence, two hand weeding (25 \& 45 DAS) and unweeded check were tested in randomized block design with three replications (Table 1). The UG-218 variety of blackgram was sown on July 10, 2015, and the harvesting occurred on October 5, 2015. The application of herbicides was provided with a knapsack sprayer using water at the rate of $600 \mathrm{l} / \mathrm{ha}$. The fertilizer dose of $20 \mathrm{~kg} \mathrm{~N}, 40$ $\mathrm{kg} \mathrm{P}_{2} \mathrm{O}_{5}$, and $20 \mathrm{~kg} \mathrm{~K} \mathrm{~K}_{2} \mathrm{O}$ was also provided. Nitrogen, phosphorus as well as potassium had been used through IFFCO 12:32:16 and urea (46\%) at sowing. 
Table 1 Effect of weed management treatments on nutrients uptake by weeds and on soil nutrients availability

\begin{tabular}{|c|c|c|c|c|c|c|c|c|}
\hline \multirow[t]{2}{*}{ Treatment } & \multirow[t]{2}{*}{ Time of application } & \multirow{2}{*}{$\begin{array}{l}\text { Weed dry weight } \\
\text { at harvest* }\left(\mathrm{g} \mathrm{m}^{-2}\right)\end{array}$} & \multicolumn{3}{|c|}{$\begin{array}{l}\text { Nutrients uptake by } \\
\text { weeds }\left(\mathrm{kg} \mathrm{ha}^{-1}\right)\end{array}$} & \multicolumn{3}{|c|}{$\begin{array}{l}\text { Available nutrients } \\
\qquad\left(\mathrm{kg} \mathrm{ha}^{-1}\right)\end{array}$} \\
\hline & & & $\mathrm{N}$ & $\mathrm{P}$ & $\mathrm{K}$ & $\mathrm{N}$ & $P$ & $\mathrm{~K}$ \\
\hline Imazethapyr@70 & Pre-emergence & $8.7(75.6)$ & 15.9 & 2.5 & 11.6 & 305.5 & 34.8 & 261.1 \\
\hline Imazethapyr@80 & Pre-emergence & $7.2(51.7)$ & 11.4 & 1.9 & 9.2 & 309.6 & 35.6 & 262.4 \\
\hline Imazethapyr@70 & 3-4 leaf stage & $11.1(122.6)$ & 24.5 & 3.5 & 20.7 & 285.2 & 32.7 & 243.6 \\
\hline Imazethapyr@80 & 3-4 leaf stage & $10.3(107)$ & 21.9 & 3.0 & 19.9 & 286.4 & 33.0 & 247.5 \\
\hline Imazethapyr+imazamox @70 & Pre-emergence & $6.0(35.8)$ & 6.2 & 1.2 & 5.1 & 321.4 & 36.3 & 271.1 \\
\hline Imazethapyr+imazamox @80 & Pre-emergence & $4.8(23.3)$ & 3.6 & 0.8 & 2.5 & 323.9 & 37.1 & 274.7 \\
\hline Imazethapyr+imazamox@70 & 3-4 leaf stage & $9.6(92.7)$ & 20.4 & 2.9 & 18.0 & 294.1 & 33.2 & 252.0 \\
\hline Imazethapyr+imazamox@80 & 3-4 leaf stage & $8.6(73.6)$ & 16.6 & 2.8 & 14.2 & 296.9 & 33.4 & 254.8 \\
\hline Pendimethalin@1000 & Pre-emergence & $9.3(85.9)$ & 17.5 & 2.6 & 12.3 & 302.7 & 34.3 & 259.8 \\
\hline Imazethapyr + pendimethalin @1000 & Pre-emergence & $6.6(44.0)$ & 7.3 & 1.4 & 8.0 & 313.9 & 35.8 & 265.8 \\
\hline Hand weeding twice & $25 \& 45$ DAS & $2.3(4.9)$ & 1.1 & 0.2 & 0.7 & 315.8 & 35.8 & 267.9 \\
\hline Unweeded check & - & $17.1(293.6)$ & 60.7 & 7.5 & 51.8 & 281.6 & 32.1 & 214.2 \\
\hline $\mathrm{SE}(\mathrm{m}+-)$ & & 0.4 & 1.2 & 0.03 & 0.1 & 1.4 & 0.1 & 0.8 \\
\hline $\mathrm{CD}(\mathrm{P}=0.05)$ & & 1.2 & 3.7 & 0.1 & 0.3 & 4.3 & 0.3 & 2.5 \\
\hline
\end{tabular}

*Value in parentheses are the means of original values. Data transformed to square root transformation $(\sqrt{x+0.5})$

Observation on weed count was documented at 30,60 days after sowing (DAS) and at harvest by utilizing a quadrate estimating 25 $\mathrm{cm} \times 25 \mathrm{~cm}$ at two arbitrarily spots in each plot and changed over into one square meter zone. The oven-dried samples of black gram crops and weeds collected at harvest had been analyzed for nitrogen, phosphorus, and potassium content, making use of the strategy as reported by Li (1966). The uptake of the nutrients by black gram crop and weeds was computed on the foundation of the respective dry weight of theirs as follows:

$\underset{(\mathrm{kg} / \mathrm{ha})}{\text { Nutrient uptake }}=\frac{\text { Nutrient content }(\%) \times \text { dry weight }(\mathrm{kg} / \mathrm{ha})}{100}$

The 'OPSTAT' software of CCSHAU, Hisar, India was used for data statistical analysis (Sheoran et al., 1998). Analysis of variance ( ANOVA) is analyzed to check the significance of differences among the treatments by the ' $\mathrm{F}$ ' test at $5 \%$ level of significance in randomized block design. The standard error of the mean was calculated in each case. When the ' $F$ ' value from analysis of variance tables was found to be significant, the critical difference (LSD) was computed to test the significance of the difference between the two treatments.

\section{Results and Discussion}

Among the recorded weed flora, Echinochloa colona, Dactyloctenium aegyptium, and Cyperus iria had been the main weeds and constituting fifty-one, thirty-two and seventeen percent, respectively, of the complete weed flora. Some other less prevalent weeds such as Medicago denticulata, Physalis minima, Commelina benghalensis, Convolvulus arvensis as well as Sorghum halepense were present in pre-emergence treatments only while being lacked in unweeded check (except at harvest) and post-emergence treatments.

\subsection{Effect on herbicides on weeds}

Data on weed dry weight at optimum dry matter stage, i.e. at harvest has been given in table 1 . The repetitive hand weeding at 25 and 45 DAS eliminated most unwanted weeds until harvest except Dactyloctenium aegyptium which was observed at 60 DAS and its population escalated up to harvest. Pre-emergence pre-mix combination of imazethapyr + imazamox at $80 \mathrm{~g} / \mathrm{ha}$ was equally effective as a pre-emergence prepared blend of imazethapyr + imazamox at $70 \mathrm{~g} / \mathrm{ha}$, which resulted in drastically lower weed dry weight over the other herbicidal treatments. These results are in line with findings of Upadhayay et al. (2012) who have reported that application of Odyssey + adjuvant $(87.5 \mathrm{~g}+1000 \mathrm{ml} / \mathrm{ha})$ considerably decreased the weed dry weight as compared to the weedy check and other treatments when observed at 40 DAS and harvest in soybean. Further, a combination of Imazethapyr + pendimethalin at $1000 \mathrm{~g} / \mathrm{ha}$ and pre-emergence imazethapyr at 80 $\mathrm{g} /$ ha statistically behaved similarly and were the next best treatments. Owing to synergetic, enhancement, or additive 
consequences, herbicidal combinations in common were much better compared to single herbicides in effectively reducing the entire weed dry weight. Likewise, Yadav et al. (2015) found that all of the weed species have been controlled effectively by premix herbicides \{imazethapyr + imazamox (post) as well as pendimetalin + imazethapyr (pre) $\}$ as compared to the preemergence application of pendimethalin or post-emergence use of imazethapyr in black gram. Aggarwal et al. (2014) claimed that the minimum dry weight of weed was observed under two hand weedings ( $20 \& 40$ DAS) when compared with all the weed control treatments at harvest. Ram et al. (2013) and Nirala et al. (2012) likewise observed that post-emergence application of imazethapyr might be utilized effectively in minimizing the weed intensity and weeds' dry matter production in black gram and soybean. Similarly, Ram \& Singh (2011) reported that in soybean, the application of imazethapyr at $75 \mathrm{~g} / \mathrm{ha}$ at $20-25$ DAS led to the minimum weed biomass that had been considerably lower compared to the weedy check.

Owing to a considerable decrease in dry weight, all weed management treatments had drastically reduced $\mathrm{N}, \mathrm{K}$, and $\mathrm{P}$ uptake by weeds as in comparison to an un-weeded check (Table 1). Probably The lowest $\mathrm{N}$ uptake by weeds was observed in two hand weeding ( $25 \& 45$ DAS), and it was statistically similar to the pre-emergence pre-mix combination of imazethapyr + imazamox at $80 \mathrm{~g} / \mathrm{ha}$. Though it was significant compared to the pre-emergence ready mix blend of imazethapyr + imazamox at $70 \mathrm{~g} / \mathrm{ha}$ as the weeds had been adequately controlled. Twice hand weeding (25\&45 DAS) resulted in the lowest uptake of phosphorus and potassium by weeds followed by pre-emergence pre-mix combination of imazethapyr + imazamox at $80 \mathrm{~g} / \mathrm{ha}$ and ready mix combination of imazethapyr + imazamox at $70 \mathrm{~g} / \mathrm{ha}$. Unweeded check resulted in probably the highest $\mathrm{N}, \mathrm{P}$, and $\mathrm{K}$ uptake as a result of uncontrolled weed growth throughout the season. These outcomes are actually in conformity with the findings of Choudhry et al. (2012), Khot et al. (2012) and Singh et al. (2020). Any delay in weed management might end up in stripping off nutrients by weeds and depriving the crop for the same (Naeem et al., 1999).

\subsection{Effect of herbicide application on black gram}

During the experiment, the plant growth and yield parameters were significantly influenced by the weed management practices, which resulted in higher dry matter accumulation in the crop compared to the weedy check. The information on dry matter accumulation by the black gram as affected by different treatments has been provided in table 2. Among the weed management treatments, preemergence ready mix blend of imazethapyr + imazamox at $80 \mathrm{~g} / \mathrm{ha}$ resulted in the highest dry matter accumulation, followed by preemergence ready mix combination of imazethapyr + imazamox at
$70 \mathrm{~g} / \mathrm{ha}$ and two hand weeding ( $25 \& 45 \mathrm{DAS})$. These results are in agreement with Pankaj et al. (2020) those who reported that two hands weeding at 25 and 45 DAS or imazethapyr at $100 \mathrm{~g} / \mathrm{ha}$ applied at 20 DAS resulted in higher crop dry weight than the unweeded check. The decrease in population and dry weight of weeds under herbicides treatments effectively produced a favourable microenvironment for the development and growth of the blackgram. It hence enhanced the dry matter accumulation of black gram. This might be linked with better control of weeds in early growth phases of the crop, which supplied the crop plants optimal environment to make use of growth resources properly leading to improved growth of the crop. All the weed control treatments significantly enhanced the $\mathrm{N}, \mathrm{P}$, and $\mathrm{K}$ uptake by blackgram (Table 1). Nutrient uptake is characterized by plant dry matter and nutrient content. Moreover, lower N, P, and $\mathrm{K}$ removal by weeds allowed blackgram to thrive and accumulate biomass which so led to higher uptake of the nutrients. N, P, and $\mathrm{K}$ uptake was significantly highest in pre-emergence ready mix blend of imazethapyr + imazamox @ $80 \mathrm{~g} / \mathrm{ha}$. A pre-emergence available mixed blend of imazethapyr + imazamox@ 70 g/ha was the second-best treatment for N, P, and K uptake and these results were statistically similar in $\mathrm{N}$ uptake while being statistically distinct in $\mathrm{P}$ and $\mathrm{K}$ absorption with two hands weeding ( $25 \& 45$ DAS). Significantly lowest NPK uptake by black gram was observed in an un-weeded check. These results are actually in conformity with the findings of Modak et al. (1995) and Khot et al., (2012).

\subsection{Effect of herbicide application on available nutrients}

All the weed management treatments resulted in substantially higher available $\mathrm{N}, \mathrm{P}$, and $\mathrm{K}$ as compared to the un-weeded check (Table 2). The pre-emergence ready mix blend of imazethapyr + imazamox @ 80 g/ha being statistically comparable to a pre-emergence prepared mix of imazethapyr + imazamox@70 g/ha which resulted in substantially higher available $\mathrm{N}$ in the soil. Twice hand weeding ( $25 \& 45$ DAS) was the next best treatment concerning $\mathrm{N}$ availability in the soil. Available $\mathrm{P}$ in soil was maximum in the treatment where preemergence pre-mix combinations of imazethapyr + imazamox at $80 \mathrm{~g} /$ ha was applied followed by pre-emergence ready mix blend of imazethapyr + imazamox@70 g/ha. Likewise, the highest amount of $\mathrm{K}$ in soil was found in treatment where pre-emergence ready mix blend of imazethapyr + imazamox at $80 \mathrm{~g} / \mathrm{ha}$ was applied. In comparison, the second-best treatment which raised the $\mathrm{K}$ availability in soil was a pre-mix combination of imazethapyr+imazamox@70 g/ha. The maximum amount of nutrients removal was observed in un-weeded checks due to the prevalence of numerous weeds which resulted in the lowest availability of NPK in the soil after harvest. The results are actually in conformity with the findings of Khot et al. (2012). 
Table 2 Effect of weed management treatments on total nutrient uptake by crop $\left(\mathrm{kg} \mathrm{ha}^{-1}\right)$

\begin{tabular}{|c|c|c|c|c|c|c|c|c|c|c|c|}
\hline \multirow{2}{*}{ Treatment } & \multirow{2}{*}{$\begin{array}{c}\text { Time of } \\
\text { application }\end{array}$} & \multirow{2}{*}{$\begin{array}{l}\text { Crop dry matter at } \\
\text { harvest }\left(\mathrm{g} \mathrm{m}^{-2}\right)\end{array}$} & \multicolumn{3}{|c|}{$\mathrm{N}$} & \multicolumn{3}{|c|}{$\mathrm{P}$} & \multicolumn{3}{|c|}{ K } \\
\hline & & & Seed & Straw & Total & Seed & Straw & Total & Seed & Straw & Tota \\
\hline Imazethapyr@70 & Pre-emergence & 387.3 & 42.2 & 27.3 & 69.5 & 4.3 & 3.9 & 8.3 & 11.5 & 18.4 & 29.9 \\
\hline Imazethapyr@80 & Pre-emergence & 486.6 & 46.1 & 29.3 & 75.4 & 4.5 & 4.3 & 9.0 & 12.4 & 20.2 & 32.6 \\
\hline Imazethapyr@70 & 3-4 leaf stage & 149.4 & 25.4 & 20.7 & 46.1 & 2.7 & 2.2 & 4.9 & 6.7 & 10.6 & 17.4 \\
\hline Imazethapyr@80 & 3-4 leaf stage & 181.3 & 32.2 & 22.2 & 54.3 & 3.6 & 2.4 & 6.0 & 8.1 & 14.0 & 22.1 \\
\hline $\begin{array}{l}\text { Imazethapyr + } \\
\text { imazamox@70 }\end{array}$ & Pre-emergence & 535.2 & 52.6 & 35.6 & 88.2 & 5.7 & 5.6 & 11.3 & 16.2 & 28.0 & 44.2 \\
\hline $\begin{array}{l}\text { Imazethapyr + } \\
\text { imazamox@80 }\end{array}$ & Pre-emergence & 587.1 & 56.9 & 38.0 & 95.0 & 6.4 & 6.1 & 12.5 & 19.1 & 30.0 & 49.2 \\
\hline $\begin{array}{l}\text { Imazethapyr + } \\
\text { imazamox @ } 70\end{array}$ & 3-4 leaf stage & 193.8 & 33.8 & 23.0 & 56.9 & 3.8 & 2.5 & 6.3 & 9.0 & 15.8 & 24.7 \\
\hline $\begin{array}{l}\text { Imazethapyr + } \\
\text { imazamox@80 }\end{array}$ & 3-4 leaf stage & 228.2 & 36.7 & 24.3 & 61.0 & 4.0 & 2.9 & 6.8 & 9.8 & 17.2 & 27.0 \\
\hline Pendimethalin@1000 & Pre-emergence & 311.6 & 40.9 & 26.8 & 67.7 & 4.5 & 3.3 & 7.8 & 11.3 & 19.2 & 30.5 \\
\hline $\begin{array}{l}\text { Imazethapyr + } \\
\text { pendimethalin@ @ } 1000\end{array}$ & Pre-emergence & 499.7 & 48.2 & 32.8 & 81.0 & 5.1 & 4.7 & 9.8 & 13.1 & 25.5 & 38.6 \\
\hline Hand weeding twice & $25 \& 45$ DAS & 513.3 & 50.0 & 33.5 & 83.4 & 5.4 & 5.2 & 10.6 & 14.8 & 25.9 & 40.6 \\
\hline Unweeded check & - & 83.5 & 15.3 & 17.6 & 32.9 & 2.0 & 1.7 & 3.7 & 3.8 & 6.8 & 10.6 \\
\hline $\mathrm{SE}(\mathrm{m}+-)$ & & 10.6 & 1.8 & 0.8 & 2.1 & 0.1 & 0.1 & 0.1 & 0.3 & 0.4 & 0.5 \\
\hline $\mathrm{CD}(\mathrm{P}=0.05)$ & & 32.9 & 5.2 & 2.4 & 6.4 & 0.3 & 0.2 & 0.4 & 0.9 & 1.1 & 1.4 \\
\hline
\end{tabular}

\section{Conclusion}

From the results of this study, it can be concluded that preemergence of ready mix blend of imazethapyr+imazamox @ 80 $\mathrm{g} /$ ha yields the most excellent results in terms of NPK nutrients uptake by blackgram and availability of nutrients in the soil. These results were comparable with pre-emergence prepared blend of imazethapyr + imazamox@70 g/ha treatments while the highest nutrients depletion by weeds occurred in unweeded check.

\section{Conflict of interest}

The authors declare that they have no conflict of interest

\section{References}

Aggarwal N, Singh G, Ram H, Khanna V (2014) Effect of postemergence application of imazethapyr on symbiotic activities, growth and yield of black gram (Vigna mungo) cultivars and its efficacy against weeds. Indian Journal of Agronomy 59: 421-426.

Anonymous (2018) Pulses revolution from food to nutritional security. Crops Division. Ministry of Agriculture \& Farmers Welfare, Government of India.

Avinash CS, Patil BL (2018) Trends in area, production and productivity of major pulses in Karnataka and India: An economic analysis. Journal of Pharmacognosy and Phytochemistry 7: 2097-2102.
Choudhary VK, Suresh KP, Bhagawati R (2012) Integrated weed management in black gram (Vignamungo) under mid hills of Arunachal Pradesh. Indian Journal of Weed Science 57: 382-385.

Khot DB, Munde SD, Khanpara VD, Pagar RD (2012) Evaluation of new herbicides for weed management in summer black gram (VignamungoL.). Crop Research 44: 326-330.

Li LT (1966) Rapid chemical methods for determining N, P and K in plant tissues. Journal of Taiwan Agricultural Research 15: 1-5.

Mansoori N, Bahadauria N, Rajput RL (2015) Effect of weed control practices on weeds and yield of blackgram (Vigna mungo). Legume Research 38: 855-857.

Modak R, Chakraborty T, De GC (1995) Method of weed management on weed biomass, yield of black gram (Phaseolus mungo) and nitrogen uptake. Indian Journal of Agronomy 40: 115-117.

Naeem M, Ahmad S, Ali H (1999) Investigation of the critical period of weed interference with the growth and yield of mungbean. International Journal of Agriculture and Biology1: 350-352.

Nirala H, Choubey NK, Bhoi S (2012) Performance of postemergence herbicides and hand weedings with respect to their effects on weed dynamics and yields of black gram (Vignamungo). International Journal of Agricultural and Statistics Sciences8: 679-689. 
Pankaj SC, Upasani RR, Barla S, Dewangan PK, Kumar V (2020) Efficacy of pre and post-emergence herbicides in black gram crop. International Archives of Applied Sciences and Technology 11: 120-131.

Ram H, Singh G (2011) Studies on the bio-efficacy of herbicides for weed control in soybean (Glycine max) under different sowing methods. Indian Journal of Ecology 38: 11-13.

Ram H, Singh G, AggarwalN, Buttar GS, Singh O (2013) Standariztion of rate and time of application of imazethapyr weedicide in soybean. Indian Journal of Plant Protection 41:33-37.

Rana SS, Sharma N, Badiyala D (2019b) A preliminary study on the time of application of imazethapyr and its ready mix combination with pendimethal in and imazamox against weeds in blackgram. Journal of Research in Weed Science 2: 282-291.

Rana SS, Singh G, Rana MC , Sharma N, Kumar S, Singh G, Badiyala D (2019a) Impact of imazethapyr and its ready mix combination with imazamox to control weeds in black gram. Indian Journal of Weed Science 51: 151-157.

Sanbagavalli S, Chinnusamy C, Marimuthu S, Sivamurugan AP (2016) Weed management strategies in Blackgram (Phaseolus mungo L..): A review. International Journal of Agricultural Sciences 8: 3481-3486.

Sasikala K, Ashok P, Mahapatra J (2019) Weed Management through New Generation Herbicides in Blackgram (Vigna mungo L.)- A Review. Bulletin of Environment, Pharmacology and Life Sciences 8: 1-5.

Sheoran OP, Tonk DS, Kaushik LS, Hasija RC, Pannu RS (1998) Statistical Software Package for Agricultural Research workers. In: Hooda DS, Hasija RC (Eds.), Recent Advances in Information Theory, Statistic \& Computer Applications CCSHAU, Hisar, Pp. 139-143.

Shweta, Malik M, Amandeep (2017) The critical review on integrated weed management in urd bean. International Journal of Current Microbiology and Applied Sciences 6: 88-96.

Singh AK, Singh RS, Singh AK, Kumar R, Kumawat N, Singh NK, Singh SP, Shanker R (2020) Effect of Weed Management on Weed Interference, Nutrient Depletion by Weeds and Production Potential of Long Duration Pigeonpea (Cajanus cajanL.) under Irrigated Ecosystem. Inetrnational Journal of Current Microbiology and Applied Sciences 9: 676-689.

Sondhia S, Varshney JG (2010) Herbicides. Satish Srial Publication House, Delhi.

Stagnari F, Maggio A, Galieni A, Pisante M (2017) Multiple benefits of legumes for agriculture sustaianability: an overview. Chemical and Biological Technologies in Agriculture 4: 1-13.

Tan S, Evans RR, Dahmer ML, Singh BK, Shaner DL (2005) Imidazolinone-tolerant crops: history, current status and future. Pest Management Science.61: 246-257.

Tiwari AK, Shivhare AK (2016) Pulses in India: Retrospect and Prospects. Govt of India, Ministry of Agriculture and Farmers' Welfare (DAC\&FW), Directorate of Pulses Development, Vindhyachal Bhawan, Bhopal, MP. Publication No: DPD/Pub.1/Vol 2/2016, pp 221. (http://dpd.dacnet.me.in).

Upadhyay VB, Singh A,Rawat A (2012) Efficacy of early postemergence herbicides against associated weeds in soybean. Indian Journal of Weed Science 44: 73-75.

Upasani RR, Barla S, Hassan D, Puran AN (2017) Weed management in blackgram and its residual effect on succeeding mustard crop. Indian Journal of Weed Science 49: 346-349.

Yadav KS, Dixit JP, Prajapati BL (2015) Weed management effects on yield and economics of black gram. Indian Journal of Weed Science 47: 136-138. 